\title{
USE OF ENERGY IN POLISH AGRICULTURE
}

\author{
Marcin Wysokinski ${ }^{1}$, Ph.D.; Paulina Trebska ${ }^{2}$, M.Sc.; Arkadiusz Gromada ${ }^{3}$, M.Sc. \\ $1,2,3$ Warsaw University of Life Science
}

\begin{abstract}
Energy consumption plays a fundamental role in a modern society. One of the objectives of sustainable development of agriculture and rural areas is the efficient use of energy at agricultural holdings. The energy needs of rural areas have been growing along with the development of civilization. The energy needs of the agricultural sector are largely influenced by the social and economic structure of Polish rural areas. Poland has a relatively high energy consumption in agriculture, including very low consumption of energy produced using renewable sources. The objective of this article is to assess of energy use in Polish agriculture. The analysis uses data obtained from Statistics Poland.
\end{abstract}

Key words: energy efficiency, energy consumption, energy management, agriculture, agricultural holdings. JEL code: $013, \mathrm{P} 18, \mathrm{P} 4$

\section{Introduction}

Climate changes and their consequences are becoming increasingly apparent, particularly in agriculture (Baran, 2015). Stopping or slowing down these consequences is possible, inter alia, by improving energy efficiency. The duty to improve efficient energy use and, therefore, the need to save energy, results from the energy and climate policy adopted in Poland. This policy is primarily shaped by the EU acquis. Key regulations include: Directive 2009/28/EC on the promotion of the use of energy from renewable sources, and Directive 2009/29/EC amending Directive $2003 / 87 / E C$ so as to improve and extend the greenhouse gas emission allowance trading scheme of the Community, which are included in the climate and energy package. This package assumes that, by 2020:

- emissions of greenhouse gases will be reduced by $20 \%$ in EU countries;

- energy efficiency will be increased to save $20 \%$ of its consumption;

- renewable energy will reach $20 \%$ in the total energy consumption (for Poland, this target is set at $15 \%$ ) (Bienkowska - Golasa, 2016).

Energy is the basis for development of civilization. The ethical dilemma arises in terms of its correct use and keeping its sources for future generations. This approach is associated with ecophilosophy. Use of renewable energy sources is one of the methods to assure sustainable development. The European Union policy aims to reduction energy consumption and increase use of renewable sources of energy in the economy (Rokicki, 2016; Wicki, Wicka, 2016).

The need to take action to increase energy efficiency concerns our lives with respect to all levels: activity of the state, local authorities, enterprises, agricultural holdings, and households.

People need to manufacture and consume energy efficiently, provided that they don't disturb the balance of the ecosystem, and the natural and shaped environment will be left to future generations in a higher state of sustainability than at present (Wojcicki, 2006).

The execution of sustainability goals also involves the prevalence of distributed low-output energy sources, generating power locally and directly for the needs of agricultural holdings or households. These criteria are best met by renewable energy installations, such as biomass boilers, micro-scale biogas plants, small wind turbines and solar collectors. The use of these technologies in agriculture results-through independent energy production-in the decrease of the size and cost of its external purchase, which delivers quantifiable financial benefits. It can also contribute to decreasing the burden of agricultural production by using animal or plant production remnants, e.g. slurry or straw, for energy generation, leading to better cost-saving effects with respect to secure 
storage or disposal of such materials. Efficient use of these sources results in quantifiable benefits at the level of a single agricultural holding, as well as the entire agriculture.

Agriculture was and is both a consumer and producer of energy. The development of energyrelated properties of agriculture, proposed by scientists and practitioners, introduces a new quality of agricultural management. Quantifiable economic benefits for farmers and residents of rural areas will come from the substitution of non-renewable fuels (coal, gas, liquid fuels) for locally-produced renewable fuels. The pursuit of local self-sufficiency of agriculture is an important part of developing energy security.

Operation of a modern agricultural holding is strictly closely linked with the need to respond to growing energy demands, in particular, the demand for electricity. Energy spending constitutes a significant share of costs of agricultural holdings (Cwil et al., 2017).

Heat in agricultural holdings is required not only to provide comfort of living for residents -it is also used in agricultural production and small-scale food processing at the holding. An agricultural holding's energy demand can be split into two main groups (Oniszk-Poplawska A. et al., 2011):

- demand for utility purposes-room heating, hot water, use of electricity for lighting and powering household appliances,

- demand for direct agricultural purposes-irrigation, drying, cultivation of greenhouse plants, animal husbandry, fuel for agricultural machines.

Improving heat use efficiency in agricultural holdings directly translates to their upkeep costs and the final economic output.

Energy is a significant component of agricultural production expenses. Energy consumption is affected by changes in the scope and technology of agricultural production, increase in prices of energy carriers and decrease in the number of entities included in the category of agricultural holdings. The energy needs of the agricultural sector are largely influenced by the social and economic structure of Polish rural areas.

The objective of this article is to assess of energy use in Polish agriculture. Specific objectives of the article are:

- analysis of reasons of energy consumption in selected areas of agriculture,

- identification of structure of final energy consumption in Poland broken down by sector 20052015,

- presentation of changes in final energy consumption in agriculture in 2005-2015,

- presentation of direct energy consumption in agriculture broken down by key energy carriers in 2010-2015.

\section{Research results}

The agricultural sector covers a range of plant and animal activity types. Heating, lighting, air ventilation and circulation, and cooling constitute main energy-intensive areas of energy consumption in agriculture (Carbon Trust, 2006). Heating is a process with a significant impact on energy costs in agriculture and horticulture (Oniszk-Poplawska A. et al., 2011). 
Energy consumption in agriculture and selected areas of agriculture

\begin{tabular}{|l|l|}
\hline \multicolumn{1}{|c|}{ Area } & \multicolumn{1}{c|}{ Energy consumption } \\
\hline Horticulture & heating takes up $90 \%$ of energy consumed by a greenhouse \\
\hline Pig husbandry & $\begin{array}{l}\text { systems of animal care and feeding } \\
\text { construction services, environmental protection, waste management, emissions control }\end{array}$ \\
\hline $\begin{array}{l}\text { Poultry } \\
\text { husbandry }\end{array}$ & systems of maintaining good environmental conditions for the flock \\
\hline $\begin{array}{l}\text { Dairy } \\
\text { production }\end{array}$ & $\begin{array}{l}\text { milk cooling systems and heating systems constitute approx. } 65 \% \text { of energy used } \\
\text { lighting, processes related to industrial pump use }\end{array}$ \\
\hline $\begin{array}{l}\text { Plant } \\
\text { production }\end{array}$ & $\begin{array}{l}\text { maintaining proper insulation, temperature, storage; keeping the right balance between } \\
\text { internal and external temperature } \\
\text { in mixed production: storage and drying }\end{array}$ \\
\hline \multicolumn{2}{|l}{ Source: Goscianska-Lowinska J., 2015 }
\end{tabular}

In the structure of final energy consumption in Poland in 2015, the largest consumption was noted in households (31\%), transport (27\%) and industry (24\%). The lowest consumption was noted in agriculture (5\%) and services (13\%). In 2005-2015 in Poland, we noted an increase in the share of the final energy consumption of transport and service industries, and a decrease in the share of industry, households and agriculture. Agricultural share dropped from 8 to $5 \%$. The drop and the relatively small share of agriculture in final energy consumption were due to the increase in the importance of sectors of the economy such as transport and services in generating gross domestic product. Another reason is the increase in energy efficiency in agriculture (Table 3).

Structure of final energy consumption in Poland broken down by sector in 2005-2015

\begin{tabular}{|l|c|c|}
\hline \multicolumn{1}{|c|}{ Sector } & $\mathbf{2 0 0 5}$ & $\mathbf{2 0 1 5}$ \\
\hline Industry & $26 \%$ & $24 \%$ \\
\hline Transport & $21 \%$ & $27 \%$ \\
\hline Households & $34 \%$ & $31 \%$ \\
\hline Agriculture & $8 \%$ & $5 \%$ \\
\hline Services & $11 \%$ & $13 \%$ \\
\hline Total & $100 \%$ & $100 \%$ \\
\hline
\end{tabular}

Source: author's calculations based on data from Statistics Poland, 2017

Energy consumption in agriculture decreased slightly between 2005 and 2015 ( -1.2 Mtoe). This was influenced by the decrease of agricultural activity ( -0.1 Mtoe) and the increase in energy efficiency in agriculture ( -1.0 Mtoe), which means that the consumption drop resulted from energy efficiency.

Impact of variables on the change in final energy consumption in 2005-2015 (Mtoe)

\begin{tabular}{|l|c|c|c|c|c|c|}
\hline \multicolumn{1}{|c|}{ Item } & Households & Industry & Transport & Services & Agriculture & Total \\
\hline Change in consumption & -0.8 & -0.4 & 4.5 & 1.0 & -1.2 & 3.1 \\
\hline \multicolumn{7}{|c|}{ VARIABLES } \\
\hline Activity & - & 5.0 & 6.9 & 2.6 & -0.1 & 14.3 \\
\hline Number of apartments & 2.1 & - & - & - & - & 2.1 \\
\hline Lifestyle & 1.4 & - & - & - & - & 1.4 \\
\hline Structural changes & - & 0.2 & 1.7 & - & - & 1.9 \\
\hline Energy efficiency & -1.2 & -5.5 & -3.4 & 0.0 & -1.0 & -11.1 \\
\hline Weather conditions & -1.6 & - & - & -0.7 & - & -2.2 \\
\hline Other & -1.5 & -0.1 & -0.6 & -0.9 & -0.1 & -3.2 \\
\hline
\end{tabular}

Source: author's calculations based on data from Statistics Poland, 2017 
According to Statistics Poland, direct energy consumption in agriculture in 2010-2015 is characterized by a decreasing trend. In 2015, direct energy consumption reached the value of $137716 \mathrm{TJ}$, which-compared to 2010-is a result that is lower by over 22 thousand (Fig. 1). Decreasing in total energy consumption in Polish agriculture is the result of the progressive agricultural land and sown area reductions. Increase in energy consumption in 2013 was caused, inter alia, variability of weather conditions and crop yields (Pawlak, 2016).

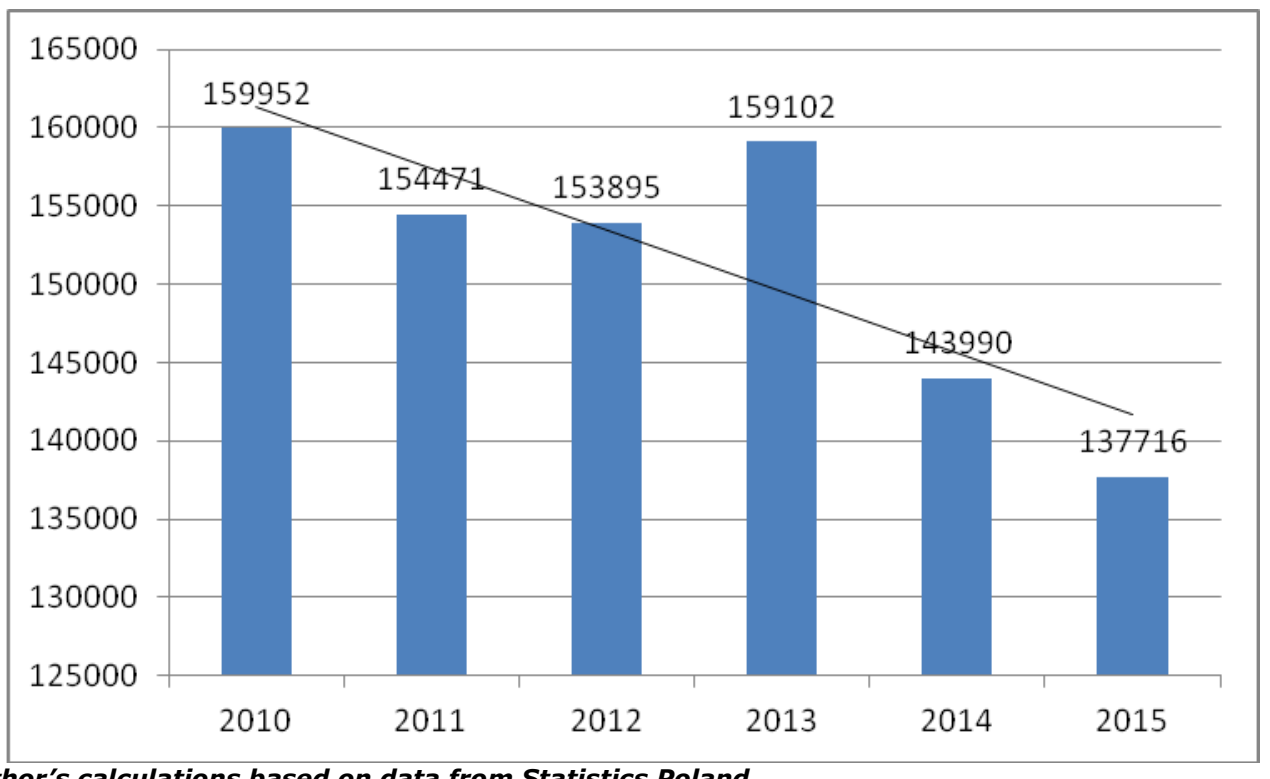

Source: author's calculations based on data from Statistics Poland

Fig. 1. Direct energy consumption in agriculture in 2010-2015 (TJ)

Rural holdings are primarily based on distributed energy sources. In the European Union, refinery products, mainly gasoline, diesel fuel and fuel oil form the main source of meeting energy needs of agriculture, covering over $50 \%$ of this sector's needs. However, current trends indicate that renewable energy will become the most dynamically developing industry having use in rural areas (Oniszk-Poplawska A. et al., 2011).

In 2015, 1400 thousand tons of bituminous coal, 70 thousand tons of light fuel oil, and 57 thousand tons of liquefied petroleum gas (LPG) were consumed in agriculture. Despite the advancing gasification of rural areas, agriculture and rural households still consume large amounts of coal for energy purposes. Coal is an exceedingly burdensome source of so-called low emission, which also decreases the quality of living in rural areas. This trend takes place despite a significant increase in the price of coal for individual customers. Electrical energy consumption in 2010-2015 in agriculture decreased from 1616 GWh in 2010 to 1507 GWh in 2015.

Official statistics are incomplete with respect to the use of renewable energy sources in agriculture. They primarily omit small-scale, non-commercial sources that are not connected to an electrical, gas and heat distribution grid, such as solar collectors, small wind farms, household biomass boilers using locally available energy sources in the form of agri-biomass, i.e. of agricultural origin. Renewable energy sources in rural areas still haven't found mass use. The most important source of renewable energy for Polish agriculture - biogas and biomass (Wojcicki, 2007). Biomass energy consumption in agriculture, according to 2015 estimates, was $116 \mathrm{TJ}$, while biogas consumption reached $385 \mathrm{TJ}$. 
Direct energy consumption in agriculture broken down by key energy carriers in 2010-2015

\begin{tabular}{|l|c|c|c|c|c|c|}
\hline \multicolumn{1}{|c|}{ Energy carrier } & $\mathbf{2 0 1 0}$ & $\mathbf{2 0 1 1}$ & $\mathbf{2 0 1 2}$ & $\mathbf{2 0 1 3}$ & $\mathbf{2 0 1 4}$ & $\mathbf{2 0 1 5}$ \\
\hline Biogas [T]] & - & 276 & 481 & 505 & 328 & 385 \\
\hline Solid plant and animal waste-derived fuels [TJ] & 100 & 181 & 48 & 37 & 310 & 116 \\
\hline Primary energy sources [T]] & 74962 & 68696 & 68272 & 75737 & 61356 & 58187 \\
\hline Coke and semi-coke [thousand t] & 33 & 35 & 10 & 20 & 10 & 9 \\
\hline Petroleum gas [thousand t] & 50 & 51 & 50 & 50 & 60 & 57 \\
\hline Diesel fuel I [thousand t] & 1600 & 1610 & 1625 & 1600 & 1604 & 1550 \\
\hline Light fuel oil [thousand t] & 100 & 102 & 100 & 80 & 70 & 70 \\
\hline Heavy fuel oil [thousand t] & 23 & 31 & 34 & 24 & 11 & 10 \\
\hline Steam coal [thousand t] & 1760 & 1600 & 1650 & 1969 & 1500 & 1400 \\
\hline Non-energy-related products [TJ] & 65 & 72 & 85 & 28 & 58 & 36 \\
\hline Electrical energy [GWh] & 1616 & 1595 & 1559 & 1539 & 1500 & 1507 \\
\hline Lignite [thousand t] & 200 & 160 & 165 & 200 & 160 & 140 \\
\hline Methane-rich natural gas [million m3] & 38 & 39 & 45 & 37 & 35 & 26 \\
\hline Nitrogen-rich natural gas [million m3] & 5 & 6 & 6 & 7 & 7 & 7 \\
\hline Peat and wood [thousand m3] & 2200 & 2500 & 2200 & 2200 & 2000 & 2000 \\
\hline
\end{tabular}

Energy loss in agriculture can take place in the following cases (Oniszk-Poplawska A. et al., 2011):

- heat loss often occurs during logistics-related operations, e.g. unloading goods;

- incorrect maintenance of temperature sensors' technical condition;

- low level of automation of the heating and cooling process;

- incorrect exposure of sensors in agriculture and horticulture;

- disturbances caused by external factors, i.e. sunlight, draught, interference of other electronic devices;

- incorrect maintenance of ventilation systems;

- lack of appropriate efficiency-focused training for the staff;

- lack of a lighting management system;

- incorrect maintenance of lighting systems;

- lack of energy-efficient lighting system;

- overloading cooling systems;

- incorrect exposure of cooling equipment;

- incorrect maintenance of cooling equipment's technical condition;

- incorrect maintenance of cooling systems;

- no utility room retrofitting.

\section{Conclusions, proposals, recommendations}

1) Modern agriculture is completely dependent on external sources of energy. The primary role in this matter is held by non-renewable energy sources, which contributes to the emission of greenhouse gases and, in consequence, to the degradation of the natural environment. It is therefore natural to strive towards improved energy efficiency and changes in the structure of energy sources. The key task for the agriculture of the future is to use renewable sources of energy. 
2) An efficient energy management system, one of the requirements of modern sustainable agriculture, has then two-fold benefits: it positively impacts the natural environment and contributes to positive financial results. The costs of energy in agriculture constitute an important part of production costs, which tells us to search for reduction opportunities in order to improve production profitability.

3) Energy consumption in Polish agriculture in 2005-2015 decreased, which-along with increasing agricultural production-unequivocally indicates that energy efficiency has improved.

4) The most frequently used energy source in Polish agriculture in the studied period was petroleum and bituminous coal, in contrast to renewable energy sources, the use of which was marginal.

\section{Bibliography}

1. Baran, J; (2015); Regional Differentiation of Financial Support from the European Union and Its Impact on Agricultural Efficiency in Poland; Economic Science for Rural Development. No 38, Jelgava, Latvia, pp. 227238.

2. Bienkowska-Golasa, W (2016): Produkcja i wykorzystanie energii elektrycznej na Mazowszu z uwzglednieniem OZE (Production and Use of Electricity in Mazowsze with the Consideration of Renewable Energy Sources), in: Polityka ekonomiczna, Prace Naukowe Uniwersytetu Ekonomicznego we Wroclawiu, No 450, pp. 46-55.

3. Directive 2009/28/EC of the European Parliament and of the Council of 23 April 2009 on the promotion of the use of energy from renewable sources and amending and subsequently repealing Directives 2001/77/EC and 2003/30/EC, in: Official Journal of the European Union L 140, 5 June 2009.

4. Directive 2009/72/EC of the European Parliament and of the Council of 13 July 2009 concerning common rules for the internal market in electricity, and repealing Directive 2009/54/EC (2nd energy directive), which repealed Directive 96/92/EC, in: Official Journal of the European Union L 211, 14 August 2009.

5. Wojcicki Z., (2006). Poszanowanie energii i srodowiska w rolnictwie i na obszarach wiejskich (Saving Energy and the Environment in Agriculture and Rural Areas). Infrastruktura i ekologia terenow wiejskich, No $2 / 1 / 2006$, pp. 34-35.

6. Cwil M., Ginalski Z., Raczkiewicz D., Staroscik J., (2017). Efektywne gospodarowanie energia elektryczna i cieplna w gospodarstwie rolnym (Effective Management of Electricity and Heat on an Agricultural Holding). Fundacja na rzecz Rozwoju Polskiego Rolnictwa.

7. Carbon Trust (2006). Agriculture and Horticulture-Introducing Energy Saving Opportunities for Farmers and Growers. UK Carbon Trust.

8. Oniszk-Poplawska, A., Curkowski, A., Wisniewski, G., Dziamski, P., (2011), Energia w gospodarstwie rolnym (Energy in Agricultural Holding). Instytut na rzecz Ekorozwoju, pp. 4-17.

9. Pawlak J., (2016). Naklady energii a liczba gospodarstw i powierzchnia uzytkow rolnych (Energy Inputs and Area of Agricultural Land and Number of Farms). Problemy inzynierii rolniczej, 2016 (IV-VI); No 2 (92), pp. 53-66.

10. Rokicki, T., (2016). Sustainable Development in Energy Sector in the European Union Countries. Economic Science for Rural Development. Proceedings of the International Scientific Conference, No 43, pp. 108-116

11. Wicki, L., Wicka, A. (2016). Bio-Economy Sector in Poland and Its Importance in the Economy. Economic Science for Rural Development, No 41, pp. 219-228.

12. Wojcicki Z., (2007). Energia odnawialna, biopaliwa i ekologia (Renewable Energy, Biofuels and Ecology). Problemy Inzynierii Rolniczej, no. 2/2007, pp. 5-18.

13. Goscianska-Lowinska J., (2015). Postrzeganie efektywnosci energetycznej jako projakosciowego wyroznika gospodarstw rolnych na terenie Wielkopolski (Perception of Energy Efficiency as a Pro-quality Indicator of Farms in Wielkopolska). Doctoral Dissertation. Poznan University of Economics and Business. Faculty of Commodity Science, pp. 70.

14. Central Statistical Office, (2017). Efektywnosc wykorzystania energii w latach 2005-2015 (Energy Efficiency in Poland in years 2005-2015), pp. 6, 62. 